\title{
Canine Glioma
}

National Cancer Institute

\section{Source}

National Cancer Institute. Canine Glioma. NCI Thesaurus. Code C129297.

A brain or spinal cord tumor arising from glial cells that occurs in dogs. 